\title{
Application of Servqual and Servperf Methods to Assess the Quality of Teaching Services - Comparative Analysis
}

\author{
Agnieszka Czajkowska1 (ORCID: 0000-0002-7430-4758), Ingaldi Manuela² (ORCID: 0000-0002-9793-6299) \\ ${ }^{1}$ Faculty of Civil Engineering and Architecture, Kielce University of Technology, 25-314 Kielce. Poland. E-mail: \\ a_czajkowska@o2.pl, \\ ${ }^{2}$ Faculty of Management, Czestochowa University of Technology, 42-201 Częstochowa. Poland. E-mail: ma- \\ nuela.ingaldi@wz.pcz.pl,manuela@gazeta.pl
}

The features of quality, which is an ambiguous, gradual and very subjective concept, cause that there is no one absolute standard for it. Scientists are looking for ways of its evaluation and improvements of the existing methods. It relates to various areas, but at the same time it is also complex and multifaceted. There are so many definitions of quality that are constantly evolving. In the paper two methods Servqual and Servperf to assess the quality of teaching services were used. The aim of the paper was to compare the results of the service quality analysis with use of both methods and to indicate the differences between them. It was also checked whether conclusions regarding the quality of services differ depending on the used research method. The Servqual method takes into account the individual expectations of the respondents, which may affect the assessment of the actual service. It is more complicated, but the results are more adequate to the specifics of the service. It was shown that in one of the areas the results concerning the quality of teaching services differed significantly depending on the used method. However, according to the literature review and presented analisys it is not possible to indicate which of these two scales to use to properly measure the service quality.

Keywords: Quality, Service, Servqual, Servperf

\section{Introduction}

No matter how old we are, what school we finished, where we live, what kind of work we perform, how much we earn, how healthy we are, we all use different type of services. Some services are used every day, others not so often. But what it is important, they are present is every step of people's lives.

The service industry belong to those which play an important role in the overall economies. The 21 st century is considered the century of the service industry. The current situation in the world changes the structure of services and their distribution channels, which is also an interesting phenomenon.

This industry follows the same rules as any other type of industry. Service companies need a variety of resources to develop services. Different types of information, e.g. on what the service is supposed to be, what its characteristics must be and when it should be delivered, are needed. Services, like products, must meet the expectations / requirements of customers, and thus must be of appropriate quality.

There is a lot of competition on the service market. Companies must fight to survive and convince present and possible customers to order services from them. What is more, except the prices, these services must be prepared, manufactured, provided according to customers' requirements, so they will cause their satisfaction. That is why every enterprise should think how to maintain the quality of their services. Service companies began to look for appropriate solutions and methods that could be useful to assess and improve the quality of these services. Service companies began to look for appropriate solutions and methods that could help them to achieve it.

The service quality has become a kind of measure which explains how much the provided service meets the customer's expectations. The enterprises found how to increase profits and market share. To do so they have to think how to improve the service quality.

It should be emphasized that a customer satisfied with the service is likely to return to the company, and that he can recommend these services to his family and friends. Perhaps he will share this fact on internet forums or social networks. And that can cause the appearance of other potential customers.

The literature offers many methods that can be used in order to assess the service quality. Among them, the Servqual and Servperf methods are the most popular and the most often described.

The Servqual method is the best known, most frequently used and described method of assessing the service quality. Its history dates back to the 80 s of the twentieth century. It was created by Parasurman, 
Zeithaml and Berry, and their first results were published in the work [1]. In this method, the basis is to compare customer expectations regarding a given service with the perception (reception) of the provided service [2].

Customers create their expectations based on their previous experiences, advice from friends and marketing, and information about competitors. It is possible that the customer's expectations for a chosen service can increase if the service is not delivered as it was ordered. Expectations are often a benchmark in customer assessment.

Perception is customer's proper opinion about something that is judged and changes from customer to customer because each customer has different expectations about certain services that play an important role in determining his level of satisfaction. Customer satisfaction is the difference between customer perception and expectations regarding service quality. In many cases, customer perception is subjective, because, as already mentioned, it changes from customer to customer, however, it provides useful data for the enterprise how to develop their marketing strategies. Customer perception and his satisfaction are two values closely related to each other, because if the ready service and the perception of its performance are close to the customer's expectations, it results in his satisfaction [3].

A positive result of difference between perception and expectations means customer satisfaction. The higher the value the better. On the other hand, a negative result means customer dissatisfaction, but also the need to search for potential areas for improvement [4].

The Servperf method is the second one described in the paper. It was created by Cronin and Taylor, and its basics were published in papers $[5 \div 7]$. The creators of this method had doubts about the measurement of the customer expectations. When defining their requirements, customers may have a negative attitude to the service, but also assess their expectations excessively high. The concept of Cronin and Taylor is built on the theory that the perception of the actual service is sufficient to provide a measure of the quality of a given service. This method is usually used when there is a high probability of relatively maximum customer expectations in relation to each of the analyzed criteria (attribute). The aim of the effective measurement is to check the performance of the research service organization and to identify places where improvements should be introduced [8]. The service quality is measured with a semantic scale (Likert scale), where 1 means poor, and the highest level excellent. The service quality assessed with this method is the better, when the individual assessment are closer to the maximum level [9]. Both methods are used to assess diffe- rent types of services. Their methodology and conclusions resulting from them differ significantly. In the literature, it is possible to find supporters of both methods. While writing this paper, the authors often argued, pointing the advantages and disadvantages of each method. That is why it is worth taking a closer look at both methods and compare them.

The aim of the paper was to compare the results of the service quality analysis with use of two methods and to indicate the differences between them. It was also checked whether conclusions regarding the quality of services differ depending on the used research method. The available literature was analyzed and both methods were also compared practically to assess the quality of a chosen service. In this paper educational services offered by one of the Polish technical universities was assessed.

\section{Literature review}

Constant progress, technology development, and strong, growing competition in the market make that the quality is a very important factor in the fight for a customer. Quality is a factor of competition in both the goods and services market. Service providers need to look for ways to convince customers that their services are competitive and at a level that is adequate to the expectations of buyers/customers [10 $\div 13]$.

There are many definitions of quality, which results from its ambiguity, gradation and relativity. It is defined as "meeting customer requirements" [14], "compliance with internal and external requirements" [15], "a composition of characteristics, marketing, production, product or service design that will meet the customer's needs" [16]. Tkaczyk believes that "quality is the totality of properties of a product or service that determine the ability of a product or service to meet identified or anticipated needs" [17]. On the other hand, Nowotarska-Romaniak defined service quality as the level at which a given service meets customer expectations and fulfills its purpose [18], as illustrated by the formula (1):

$$
\text { Quality }=\frac{\text { Actual state }}{\text { Expectations }}
$$

The factors determining the quality of material goods and the quality of services differ from each other, which results from their specificity. The quality of goods is assessed by checking specific features that were included in the design, technical documentation or order. The level of service quality can only be assessed by careful analysis of the customer's experience related to the provided service. Analysis of the service quality is a complicated problem due to its nature. The service quality is characterized by such features as: immateriality, impermanence, heterogeneity, inseparability, individuality and no possibility of acquisition $[19 \div 22]$. 
It should be emphasized, however, that the difference between goods and services is often difficult to see. This is due to the fact that in the case of products we are dealing with both tangible and intangible elements. Thus, we can distinguish pure goods, material goods with elements of services, hybrids, services with elements of material goods and pure services [23].

In the literature it is possible to find many methods which are very useful to assess the service quality. In the paper two very popular methods: Servqual and the less complicated and much simpler, although based on similar principles, the Servperf method are used.

The Servqual method, created in 1983-1985 by Berry, Parasuraman and Zeithaml and described in paper [1], is based on determining the difference between the customer's perception of the experienced and received service and his expectations for the service [24]. In the Servqual method a multi scale is used, which help to measure the service quality from the point of view of the customer and his experience, to get many advices on how to improve the quality of the offered services [9].

The survey used in Servqual consists of three parts. In the first two, the respondent answers around 22 questions, which fall into five areas: materiality, reliability, punctuality, professionalism and empathy. $\mathrm{He}$ answers these questions twice, before and after receiving the service, assessing own expectation towards this service and his experience after this service is provided.

Perception is an opinion or assessment of the delivered service which can be different depending on the customer, because it is very subjective and plays a significant role in building customer's satisfaction. And the level of his satisfaction is determined by the difference between customers' perception and expectations regarding the service quality $[25 \div 27]$. Customer's satisfaction can be expressed according to the formula [28]:

$$
S Q=\sum_{i=1}^{k}\left(P_{i}-E_{i}\right)
$$

Where:

$S Q_{i}=$ perceived service quality of the chosen service,

$k=$ number of service attributes/items,

$P=$ perception of the chosen service with respect to performance of a service firm attribute ' $?$,

$E=$ service quality expectation for attribute ' $?$ ' that is the relevant norm for chosen service.

The customer assesses the expectations and perceptions of a given service using a semantic scale (Likert scale), where 1 means poor, and the highest level excellent. He also assesses the importance of individual areas, e.g. by dividing 100 points between these areas [27].

The Servqual method can be broadly used, so it can be implicated to assess the quality of all services. The big benefit of this method it that the enterprise can improve quality, increase customer satisfaction, and thus increase competitiveness with its use. The main element of the Servqual analysis is to calculate the difference between the two ratings given by customers, i.e. expectations and perception of the finished service. This difference can also include the weights of individual areas. Additionally, average expectation and perception can be also calculated.

The Servperf (Service Performance) method was developed by J. J. Cronin and S.A. Taylor and presented in papers $[5 \div 7]$. Cronin and Taylor, claimed that it is impossible to explore the customer expectations, because they are ambiguous and variable. The customer can change their minds and requirements very easily.

The Servperf has some similarities to the Servqual method developed by Berry, Parasuraman and Zeithaml, but is less time-consuming [28]. The Servperf was created as an answer to the Servqual method. In the extensive literature on the service quality many scientists indicate too high assessment of customers' expectation as a weak point of Servqual. Already before to order the service, customers can have skeptical feeling towards the service because od their requireements, what is more, they can assess their expectation too high [29, 9, 30].

Servperf also includes around 22 statements to which the respondent refers once. The main difference which can be noticed in case of the Servqual and the Servperf methods is that in the first method the experienced quality is compared to the expected quality, while in the second method, the experienced quality is compared to the ideal quality [30]. That is why the Servperf analysis is simpler and less time-consuming [31].

As mentioned before, in this method, as in the Servqual method, we also use a questionnaire consisting of around 22 questions or statements (this is the original version and the quantity is adjusted depending on the specificity of the services whose quality we assess) [28], containing issues related to the five elements of quality discussed above (materiality, reliability, responsiveness, confidence, empathy). As in case of the Servqual method, in this case the respondent also assesses each of the elements by marking appropriate points according to the semantic rating scale (Likert scale) [32].

This method compares the results (perception) with the ideal situation, i.e. the maximum number of points in a given area [33]. The next step is to analyze the reasons of differences between the level of service quality that respondents feel and the quality of the ideal service.

According to the literature, Servperf is a more objective method than the Servqual method because the customer does not assess the expectations regarding 
the service, but he usually assess the the final form of the service $[8,34]$. The equation form (3), can be presented in the following way [28]:

$$
S Q=\sum_{i=1}^{k} P_{i}
$$

Where:

$S Q_{i}=$ perceived service quality of the chosen service,

$k=$ number of service attributes/items,

$P=$ perception of the chosen service with respect to performance of a service firm attribute '?

In terms of methodology, the Servperf method is a substantial improvement in comparison to the Servqual method. First of all, it is more efficient because it cut the amount of data by more than $50 \%$, including only perception of the ready services. On the other hand many scientists say that it has also proved to be empirically better than the Servqual scale, because it only uses one scale (perception) to explain differences in overall service quality $[35,34,9]$.

The aim of the paper is to compare both methods (Servqual and Servperf), to indicate the differences and similarities between them, and above all to check, on the example of teaching services, whether the conclusions regarding the service quality differ depending on the research method used.

\section{Methodology}

In order to assess the quality of the services provided by different types of school, it is necessary to determine the areas which are crucial for the service recipients - students, the one which causes different levels of student satisfaction. In the case of schools (also universities) individual groups of attributes had to be adapted to the specifics of their operation [36].

The research areas were presented in Figure 1.

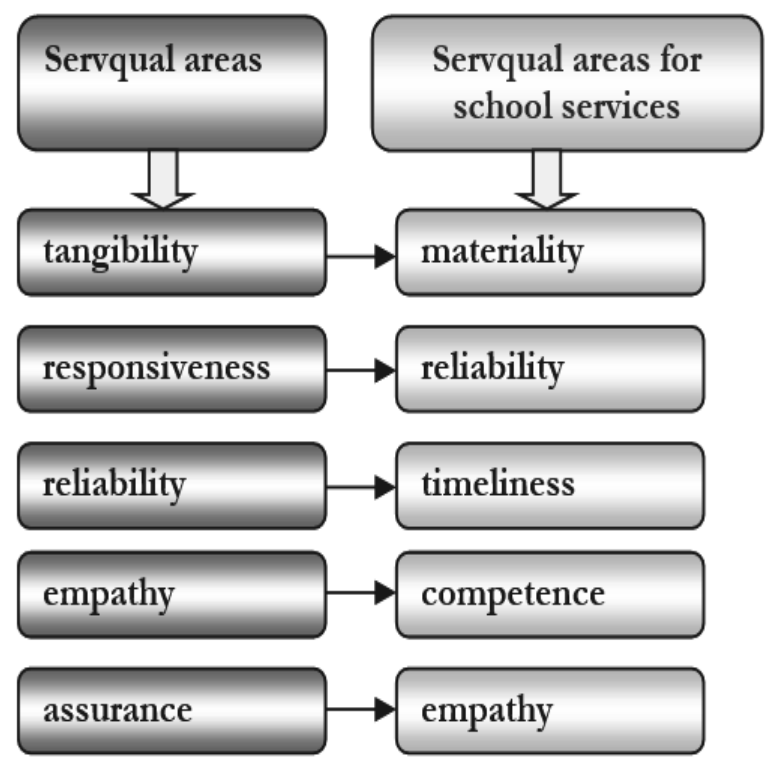

Fig. 1 Servqual areas for school services
Areas included in Figure 1 concern:

- tangibility (material elements of the service such as facilitites, equipment, machine),

- responsiveness (willingness to help the customer and provide fast service, quick response to customer requirements);

- reliability (fulfillment of the promise of providing services according to the order);

- empathy (individual approach to the customer and identification with his needs);

- assurance (professionalism, appropriate behavior of the staff).

The questionnaire was completed by 240 students of one of the technical faculties. Students were asked to complete it after their final exam, which allowed them to be objective and not afraid of teachers. The questionnaires were collected in 2018/2019 (academic year).

At the beginning the Cronbach Alpha test and standardized Cronbach Alpha test were performed for all statements together and for individual groups of statements (separately expectations and perception) to analyze the reliability of scale data which was used in the survey. The results of the Cronbach test was discussed according to the assumptions presented by Hair et al. [37]. According to these authors, results in the range (0.9-1.0) are excellent, in the range (0.8-0.9) very good, in range $(0.7-0.8)$ good, which means that they are reliable and can be further analyzed. Then, the average expectations and perception for each statement were calculated, which allowed to calculate the quality level of the research education service.

In the research, the formula (2) was used to assess the quality of teaching services with use of the Servqual method. As for the Servperf method, the authors took into account the main objection to the Servqual method and, in accordance with the Servperf method, did not take into account the individual expectations of the respondents. However, in order to facilitate the comparison of effectiveness, formula (3) was supplemented with the maximum rating according to the Likert scale (4):

$$
S Q=\sum_{i=1}^{k}\left(P_{i}-M_{i}\right)
$$

Where:

$S Q_{i}=$ perceived service quality of the chosen service,

$k=$ number of service attributes/items,

$P=$ perception of the chosen service with respect to performance of a service firm attribute ' $?$

$\mathrm{M}_{\mathrm{ij}}$ - maximum of Likert scale.

The individual results were presented graphically, 
which facilitated their analysis and drawing conclusions. Additionally, for the performed calculations, the authors propose a scale illustrating the customer satisfaction's level for both methods (Table 1).

Tab. 1 The proposal of the interpretation of customer satisfaction's level for (own study based on [38])

\begin{tabular}{|c|l|l|}
\hline $\begin{array}{c}\text { Satisfaction } \\
\text { level [\%] }\end{array}$ & Customer satisfaction's level (Servqual) & Customer satisfaction's level (Servperf) \\
\hline$<-7 ;-3>$ & $\begin{array}{l}\text { Very bad - customer extremely dissatisfied with } \\
\text { the serving employee. Perception is much } \\
\text { smaller than expectations. }\end{array}$ & $\begin{array}{l}\text { Very bad - customer extremely dissatisfied with } \\
\text { the serving employee. Perception is much } \\
\text { smaller than the maximum of Likert scale. }\end{array}$ \\
\hline$(-3 ; 0)$ & $\begin{array}{l}\text { Bad - customer dissatisfied with the serving } \\
\text { employee. Perception is smaller than expecta- } \\
\text { tions. }\end{array}$ & $\begin{array}{l}\text { Bad - customer dissatisfied with the serving } \\
\text { employee. Perception is smaller than the maxi- } \\
\text { mum of Likert scale. }\end{array}$ \\
\hline 0 & $\begin{array}{l}\text { Indifference. Perception is equal expectations. } \\
(0 ; 3)\end{array}$ & $\begin{array}{l}\text { Satisfaction. Perception is equal maximum of } \\
\text { Likert scale. }\end{array}$ \\
\hline $\begin{array}{l}\text { ployee, there are few problems in terms of cus- } \\
\text { tomer satisfaction. Perception is higher than } \\
\text { expectations. }\end{array}$ & $\begin{array}{l}\text { Very good - customer extremely satisfied with } \\
\text { the serving employee. Perception is much } \\
\text { higher than expectations. }\end{array}$ & -- \\
\hline$<3 ; 7>$
\end{tabular}

\section{Result}

In Table 2 the results of the Cronbach Alpha and standardized Cronbach Alpha test were presented. As it is seen the obtained results are in the range (0.7-0.8). Such values mean that the results for individual groups of attributes are good and all the answers can be further analyzed.

Tab. 2 Cronbach's alpha test for individual groups of statements (own study)

\begin{tabular}{|c|c|c|c|}
\hline \multirow{2}{*}{ Expectation } & Cronbach's alpha & $\begin{array}{c}\text { Standardized Cronbach Al- } \\
\text { pha }\end{array}$ & No of items \\
\hline All statements & 0.728 & 0.754 & 22 \\
\hline Materiality & 0.709 & 0.731 & 4 \\
\hline Reliability & 0.712 & 0.740 & 4 \\
\hline Timeliness & 0.753 & 0.784 & 5 \\
\hline Competence & 0.723 & 0.758 & 6 \\
\hline Empathy & 0.718 & 0.741 & 22 \\
\hline Perception & Cronbach's alpha & & 4 \\
\hline All statements & 0,739 & 0.769 & 4 \\
\hline Materiality & 0.754 & 0.791 & 3 \\
\hline Reliability & 0.731 & 0.764 & 5 \\
\hline Timeliness & 0.727 & 0.753 & 6 \\
\hline Competence & 0.716 & 0.747 & \\
\hline Empathy & 0.751 & 0.782 & \\
\hline
\end{tabular}

The results of the analysis of teaching services quality with use Servqual and Servperf methods were presented in Table 3 and Figure 2. This table contains arithmetic means of differences between the customer's expectations towards the service he wanted to get and the perception of the service which he received.
To facilitate the comparison of both methods, the example assumes that the expectations in the Servperf method are equal to the maximum value of the scale, i.e. 7. Therefore, in case of the Servperf method the individual expectations of the respondents (which is characteristic of the Servqual method) were not taken into account, but ideal quality. Results for Servqual 
analysis were described in details by authors in their paper [36]. In this paper the authors wanted to show the differences in the results obtained with use of both methods.

Tab. 3 Arithmetic means of differences between the perception $(P)$ of the received service and expectations (E) for the research education service (own study based on [36])

\begin{tabular}{|c|c|c|}
\hline Statements & Servqual & Servperf \\
\hline MATERIALITY & P-E & P-7 \\
\hline 1. Classes are equipped in modern devices & 0.12 & -0.2 \\
\hline 2. The faculty building looks attractive & 0.02 & -0.048 \\
\hline 3. Didactic and administrative employees look neatly. & 0.16 & -0.08 \\
\hline $\begin{array}{l}\text { 4. The electronic system helps deal with all the affairs connected with } \\
\text { studying }\end{array}$ & -2.37 & -2.8 \\
\hline Sum of arithmetic means & -2.07 & -3.13 \\
\hline \multicolumn{3}{|l|}{ RELIABILITY } \\
\hline $\begin{array}{l}\text { 5. Didactic employees meet deadlines. Classes are according to the } \\
\text { schedule. }\end{array}$ & 0.31 & -0.18 \\
\hline $\begin{array}{l}\text { 6. Students can expect the commitment and understanding of the dean's } \\
\text { office employees in solving problems of individual students }\end{array}$ & 0.06 & -0.02 \\
\hline 7. Students can count on the lecturer's help in solving a problem & -0.59 & -0.68 \\
\hline 8. Curricula are consistent with card of subject matter of teaching & 0.43 & -0.22 \\
\hline Sum of arithmetic means & 0.21 & -1.1 \\
\hline \multicolumn{3}{|l|}{ TIMELINESS } \\
\hline 9. Didactic employees respond to e-mails quickly & -1.02 & -1.1 \\
\hline 10. Tests are checked quickly (deadlines are met) & -0.76 & -0.88 \\
\hline 11. Employees are never too busy to respond to student's requests. & -0.8 & -1 \\
\hline Sum of arithmetic means & -2.58 & -2.98 \\
\hline \multicolumn{3}{|l|}{ COMPETENCE } \\
\hline 12. Employees care for high level of education. & -0.10 & -0.24 \\
\hline 13. Didactic employees are exacting & 1.35 & -0.28 \\
\hline 14. Didactic employees use adequate (effective) methods of evaluation. & -0.41 & -0.48 \\
\hline $\begin{array}{l}\text { 15. Didactic staffs are prepared and competent for the classes their teach. } \\
\text { Employees offer professional help. }\end{array}$ & 0.16 & -0.12 \\
\hline 16. Tests are checked with due care. & -0.08 & -0.84 \\
\hline Sum of arithmetic means & 0.92 & -1.96 \\
\hline \multicolumn{3}{|l|}{ EMPATHY } \\
\hline $\begin{array}{l}\text { 17. Each student is approached individually by the dean's office employ- } \\
\text { ees. }\end{array}$ & 0.06 & -0.02 \\
\hline 18. Consultation hours are convenient for students. & 0.04 & -0.02 \\
\hline 19. WB employees are polite and treat each student with respect. & -0.22 & -0.4 \\
\hline $\begin{array}{l}\text { 20. Plan is organized so that to ensure good organization of student's } \\
\text { work }\end{array}$ & -0.69 & -0.88 \\
\hline $\begin{array}{l}\text { 21. Employees do not understand individual student's need (their life- } \\
\text { related problems). }\end{array}$ & -1.26 & -1.54 \\
\hline 22. Students believe in goodwill of the lecturer (in their fairness) & -0.02 & -0.44 \\
\hline Sum of arithmetic means & -2.08 & -3.3 \\
\hline
\end{tabular}




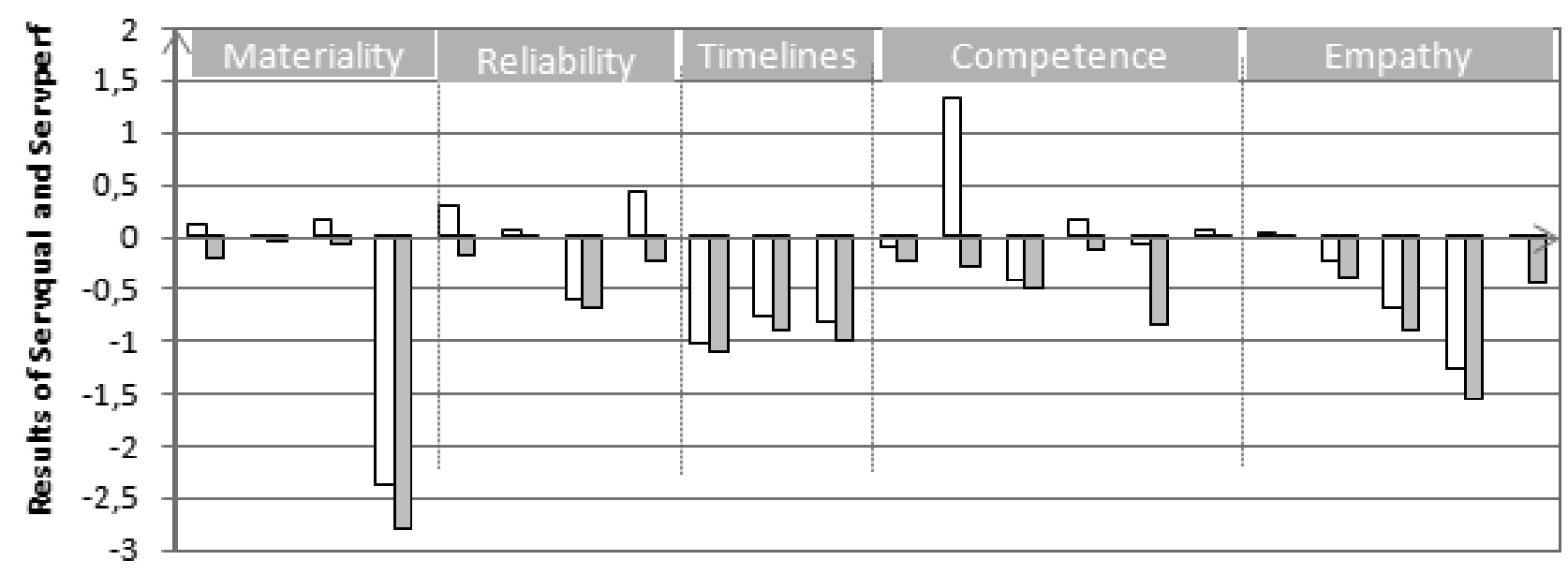
12
56
$\begin{array}{ll}7 & 8\end{array}$
Statements

\section{$\square$ Servqual $\square$ Servperf}

Fig. 2 Arithmetic means of differences between the perception $(P)$ and expectations (E) for the research education service (own study)

The analysis of Figure 2 and Table 3 showed that the positive difference between perception and expectations towards the provided service occurs in two areas: Reliability and Competence. Figure 2 also showed that student satisfaction measured with use of the Servqual method in case of ten statements $(1,2,3,5$, $6,8,13,15,17,18)$ was higher than their expectations. The Servperf method excludes such a situation, the highest degree of satisfaction for this method would be zero, and such a situation did not occur in case of any statements.

In case of the Servqual method, the greatest negative difference between perception and expectations was noted in the following statements: The electronic system helps deal with all the affairs connected with studying (4), Employees do not understand individual student's need (their life-related problems) (21). These are the areas that cause the greatest dissatisfaction of students. According to this method, these are two areas that require particular improvement. On the other hand, students stated that they were particularly satisfied with the statement $D i$ dactic employees are exacting (13).

As for the Servperf method and comparing the perception to the maximum value in the Likert scale, the results were similar. The same statements caused the greatest dissatisfaction and required particular improvement.

From Figure 2 one can also draw an interesting conclusion. If there was a great dissatisfaction with a given statement (the difference between perception and expectations), both methods confirmed it. This was the case with the following statements: 4, 7, 9, 10, 11, 20 and 21.

In the next step results for areas of statements were calculated. In this case it was possible to calculate arithmetic means and weighted arithmetic means for each area. The results are presented in Table 3.

Total arithmetic measure of differences between the perception (P) and expectations (E) (i.e. Servqual) for the research education service without including weights are -1.12 (Servqual) and -2.49 (Servperf). Taking into account the assumptions presented in Table 1, in both cases the students were not fully satisfied with the provided service. Higher dissatisfaction in the case of the Servperf method is due to the fact that the ideal quality was used for comparison, i.e. the maximum value of the scale (i.e. 7), and not the expectations of students, which were often lower than this value.

It should be emphasized that such values show need to improve the educational services provided. The values -1.12 and -2.49 are total averages collected from five areas. In order to know the actual degree of satisfaction with the service, individual areas should be analyzed after taking into account the weights.

The university should analyze the areas where dissatisfaction was the greatest in order to start changes from them, so the quality of the research educational services can be improved.

Students gave importance to specific areas. Thanks to the weights, it is known which areas are more important to the respondents. In Figure 3 the weights indicated by the respondents to particular groups of attributes were shown.

As shown in Figure 3, according to the respondents the most important group of attributes is competence while the materiality is not considered so necessary. This means that the skills and knowledge of the teacher are more important, as they actually affect the 
quality of teaching. Low-skilled teachers have nothing to offer their students.

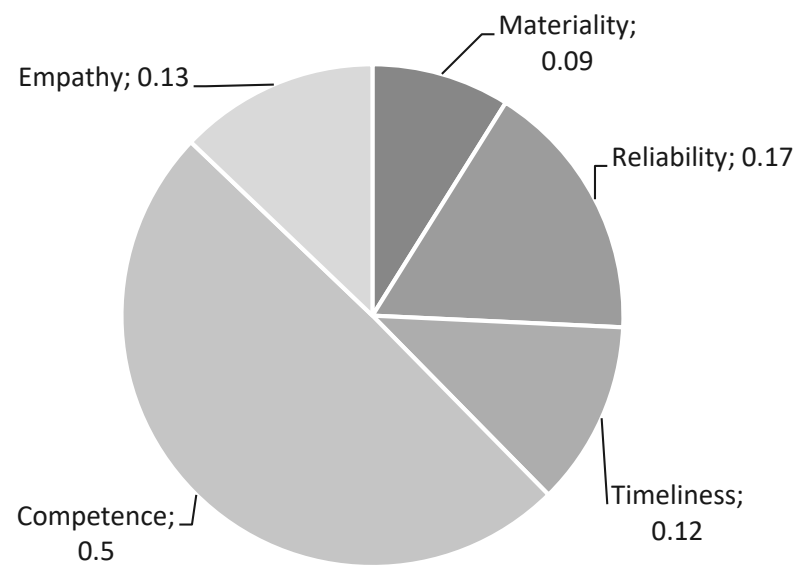

Fig. $3 \mathrm{~W}$ eights assigned by the respondents to particular areas (groups of attributes) (own study)
On the other hand, materiality is not so important, more related to the feelings and external image of the university. Of course, it's better to study in a nice, wellequipped place. However, this does not have that much impact on the learning process itself.

After considering the weights, the averages are 0.05 (Servqual) and -0.04 (Servperf). Taking into account the weights, student dissatisfaction can also be observed, again greater in the Servperf method. Again the results mean the need to raise the quality level of educational services and their improvement.

The results of the assessments according to both methods, taking into account the weights for each of the analyzed areas, were presented in Table 4 . A comparison of the weighted averages for each of the five areas using the Servqual and Servperf methods is shown in Fig. 5.

Tab. 4 Arithmetic means of differences between expectations and the perception of the research education service according to different areas (own study)

\begin{tabular}{|c|c|c|c|c|c|}
\hline \multirow{2}{*}{ Areas } & \multicolumn{2}{|c|}{ Arithmetic means without weights } & \multirow{2}{*}{ Weights } & \multicolumn{2}{c|}{ Weighted arithmetic means } \\
\cline { 2 - 4 } & Servqual & Servperf & & Servqual & Servperf \\
\cline { 2 - 5 } & -2.07 & -3.13 & 0.09 & -0.19 & -0.28 \\
\hline Materiality & 0.21 & -1.10 & 0.17 & 0.04 & -0.18 \\
\hline Reliability & -2.58 & -2.98 & 0.12 & -0.31 & -0.36 \\
\hline Timeliness & 0.92 & -1.96 & 0.5 & 0.46 & -0.98 \\
\hline Competence & -2.08 & -3.30 & 0.13 & -0.27 & -0.43 \\
\hline
\end{tabular}

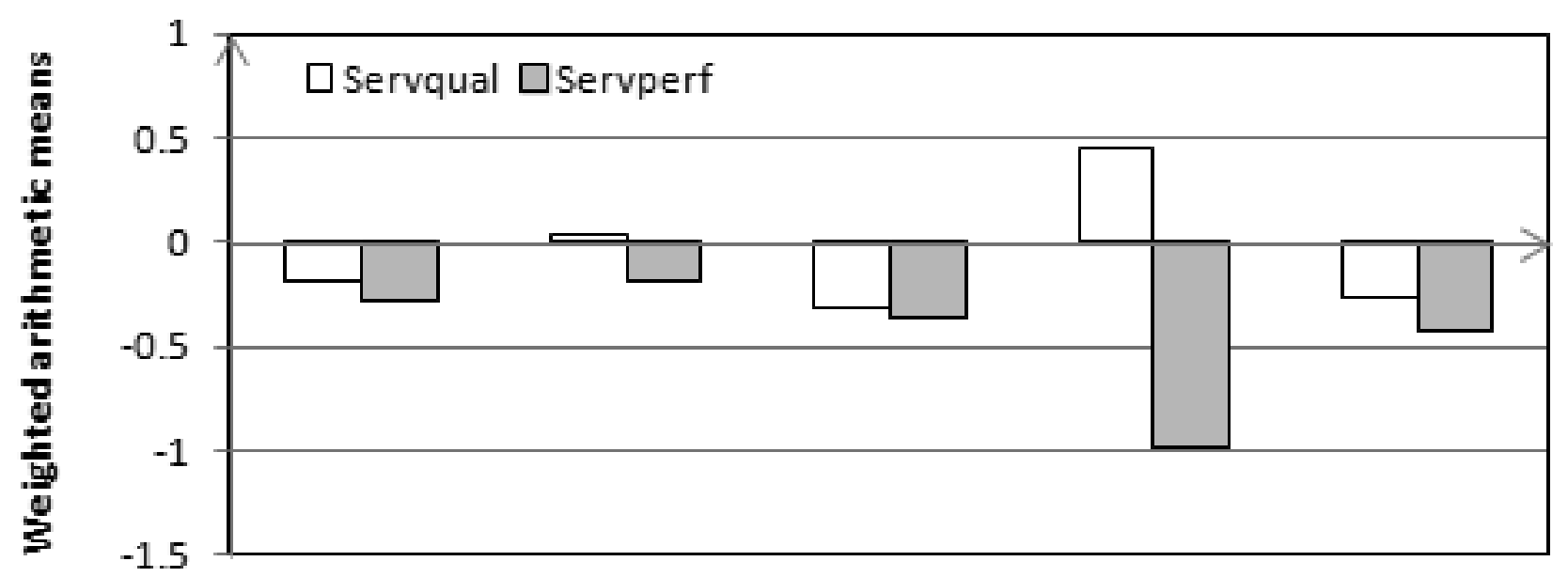

\section{Materiality Reliability Timeliness Competence Empathy}

\section{Areas for school services}

Fig. 4 Weighted averages for five areas according to the Servqual and Servperf method (own study)

In Figure 4 the exceeding of customer expectations in two areas (Reliability and Competence) in case of the Servqual method can be observed, although in the case of reliability it is a small value. Only in these two cases the satisfaction of students with the educational services of the research university was noted. The analysis shows that students' expectations in the areas of Competence and Reliability were exceeded by the 
Servqual method, while the Servperf method was assessed in negative way. In case of other areas, student dissatisfaction was noted in both analysis.

The Servqual and the Servperf methods allow determining to what extent customer expectations have been satisfied. The application of the Servqual method facilited to state that the expectations of the service users were exceeded, and the assessment of the service quality was more individual, as it depended on the individual expectations of each respondent. In the case of the Servperf method, it is not possible to exceed the customer's requirements, because they are not taken into account during the study. However, the perception can be compared to the maximum assessment that the respondent can give. The basic differences between the methods are presented in Table 5.

Tab. 5 Differences and similarities between Sevqual and Serwperf methods (own study)

\begin{tabular}{|c|c|c|}
\hline Criterion & Servqual & Servperf \\
\hline Questionnaire & $\begin{array}{l}\text { It consists of } 3 \text { parts, the first two con- } \\
\text { tain around } 22 \text { statements. }\end{array}$ & $\begin{array}{l}\text { It consists of } 22 \text { parts, the first one contains } \\
\text { around } 22 \text { statements. }\end{array}$ \\
\hline Scale & Semantic rating scale (Likert scale). & Semantic rating scale (Likert scale). \\
\hline Expectations & $\begin{array}{l}\text {-There is no clear definition of the term } \\
\text { expectations, } \\
\text { - Subjective expectations of each re- } \\
\text { spondent. }\end{array}$ & $\begin{array}{l}\text { - The expectation corresponds to the maximum } \\
\text { perfect quality, } \\
\text { - Quality perfect. }\end{array}$ \\
\hline $\begin{array}{l}\text { Results interpreta- } \\
\text { tion }\end{array}$ & $\begin{array}{l}\text { There are three variants: } \\
P=E \text { customers is satisfied } \\
P>E \text { the actual quality of the service is } \\
\text { higher than customer expectations } \\
P<E \text { the expectations of the service } \\
\text { were not met } \\
\text { There is a possibility of exceeding the } \\
\text { expectations of customer }\end{array}$ & $\begin{array}{l}\text { According to the paper there are two possibili- } \\
\text { ties: } \\
P=M \text { customers is satisfied } \\
P<M \text { the expectations of the service were not } \\
\text { met } \\
\text { The highest degree of satisfaction is when } M=P \text {. } \\
\text { Traditionally average } P \text { is calculated. }\end{array}$ \\
\hline $\begin{array}{l}\text { Type of the service } \\
\text { quality }\end{array}$ & $\begin{array}{l}\text { Relative service quality (In addition to } \\
\text { perception, customer expectations are } \\
\text { taken into account). }\end{array}$ & $\begin{array}{l}\text { The absolute service quality (only perception is } \\
\text { taken into account). }\end{array}$ \\
\hline When better to use & $\begin{array}{l}\text { - Identification of the service quality } \\
\text { shortfalls. }\end{array}$ & $\begin{array}{l}\text { - Time limit, } \\
\text { - Simplicity of conducting research, } \\
\text { - Comparison of the service quality in various } \\
\text { industries. }\end{array}$ \\
\hline
\end{tabular}

Source: own study

The Servqual method takes into account the individual expectations of the respondents. It is more complicated, but the results are more adequate to the specificity of the service and the needs of a given group of recipients.

In the case of the Servperf method, the measurement of customer expectations was questioned, as they very often change over time. Therefore, this method is based only on the customer's perception i.e. the assessment of the actual service to provide a measure of the quality of a given service and focuses on measuring and assessing the current state - it only measures and assesses the quality level of the service provided, in relation to individual categories, and then relates to the perfect image (ideal quality level). It does not take into account individual expectations.

In the literature [39-42] there are many method and tools that can be used to assess quality of products or services. All of them have their advantages and disadvantages, but at the same times they are very helpful and give different possibilities to obtain interesting results. It is up to scientists which of them it is better to use.

\section{Conclusion}

In the paper an analysis of the quality of educational services which are offered by one of the Polish technical universities was presented. The analysis was made on the basis of 240 questionnaires completed by fresh graduates of this university. The analysis was conducted with use of two methods - Servqual and Servperf. The achieved research results allowed to draw the following conclusions:

- The level of service satisfaction assessed using 
the Servperf method is lower than the level of satisfaction assessed using the Servqual method. However, the areas for the particular improvement in the first place are the same.

- Many times the expectations for the service were lower than the maximum value in the seven-point scale used in both methods (students had expectations lower than the maximum scale).

- The use of the Servperf method is easier and less time-consuming. This is due to the fact that the respondents do not have to define their expectations regarding the research service.

- The use of the Servqual method is more timeconsuming, but thanks to enabling the respondents to take into account their own scale of expectations, it becomes a more accurate method in analyzing individual (less general) conclusions. It is possible, however, that when customers defining their expectations, may have a negative attitude towards the research service or have too high expectations from the very beginning.

- It happens that the customer feels satisfied with the service (perception higher than expectation), which is impossible to detect using the Servperf method.

Despite the number of different studies in the field of service quality, it is impossible to determine which of the two scales is a better measure of service quality. Scientists around the world will argue about this for a long time.

The presented test results have certain limitations. The questionnaire, the results of which are presented in the research, was created to be used in this and previous study and may have contained elements of subjectivity. Perhaps the authors omitted some important elements that should be considered in assessing the quality of educational services. The sample size was small and covered one academic year. Perhaps a wider study would show a more accurate picture of the research educational service. The research should therefore be continued and the results compiled using both methods to confirm or disprove the conclusions presented in this article.

In the available literature, enthusiasts of both methods can be found. It should be remembered not to close oneself off on any of them. It is worth taking a closer look at the less liked one and perhaps applying both to be able to more accurately assess the quality of the chosen service.

\section{References}

[1] PARASURAMAN, A. (1985). A conceptual model of service quality and its implementation for future research. In. Journal of Marketing, 49(4), 41-50.

[2] PARASURAMAN, A., BERRY, L.L., ZEITHAML, V.A. (1991). Refinement and Reassessment of the SERVQUAL Scale. In. Journal of Retailing, 76(4), 420-450.

[3] REICHHELD, F.F. (1996) The Loyal Effect. Harvard Business School Press, Boston.

[4] STOMA M. (2012). Modele i metody pomiaru jakości ustug. Q\&R Polska Sp. z o.o., Lublin.

[5] CRONIN, J.J., TAYLOR, S.A. (1992). Measuring Service Quality: A Reexamination and Extension. In. Journal of Marketing, 56(3), 55-68.

[6] CRONIN, J.J., TAYLOR, S.A. (1994). SERVPERF versus SERVQUAL: Reconciling Performance-Based and Perceptions-MinusExpectations Measurement of Service Quality.In. Journal of Marketing, 58(1), 125-131.

[7] TAYLOR, S.A., CRONIN, J.J. (1994). An Empirical Assessment of the SERVPERF Scale.In. Journal of Marketing Theory and Practice, 14(1), 5269.

[8] YAO, Z. G.; DING, X. D. (2011). Measuring Passenger's Perceptions of Taxi Service Quality with Weighted SERVPERF.In. Applied Mechanics and Materials, 97-98, 1181-1184.

[9] INGALDI, M. (2018). Overview of the main methods of service quality analysis. In. Production Engineering Archives, 18, 54-59.

[10] KLIMECKA-TATAR, D., INGALDI, M. (2020). How to Indicate the Areas for Improvement in Service Process - the Knowledge Management and Value Stream Mapping as the Crucial Elements of the Business Approach. In. Revista Gestao \& Tecnologia-Journal of Management and Technology, 20(2), 52-74.

[11] KOWALIK, K. (2020). The role of safety in service quality in the opinion of traditional and digital customers of postal service. In. Production Engineering Archives, 26(1), 1-4, doi: $10.30657 /$ pea.2020.26.01

[12] KNOP, K. (2019). Evaluation of Quality of Services Provided by Transport \& Logistics Operator from Pharmaceutical Industry for 
Improvement Purposes. In. Transportation Research Procedia, 40, 1080-1087.

[13] FEDORKO, R., FEDORKO, I., RIANA, I.G., RIGELSKÝ, M., OLEÁROVÁ, M., OBŠATNÍKOVÁ, K. (2018). The impact of selected elements of e-commerce to e-shop recommendation. In. Polish Journal of Management Studies, 18(1), 107-120.

[14] SKRZYPEK, E. (2000). Jakosí́ i efektywność, Wydawnictwo Uniwersytetu Marii CurieSkłodowskiej, Lublin

[15] CROSBY, P.B. (1979) Quality Is Free: The Art of Making Quality Certain. McGraw-Hill, New York.

[16] FEIGENBAUM, A.V. (1991). Total Quality Control (3rd edn),McGraw-Hill, New York.

[17] TKACZYK, S. (2000). Inšznieria jakości a inşynieria materiatowa. Instytut Organizacji i Zarządzania w Przemyśle „ORGMASZ”, Warszawa.

[18] NOWOTARSKA-ROMANIAK, B. (2008). Marketing usług zdrowotnych. In. Koncepcja $i$ stosowanie. Wolter Kluwer Polska, Kraków.

[19] PARASURAMAN, A., BERRY, L.L., ZEITHAML, V.A. (1991). Servire Qualità. McGraw-Hill, Milano.

[20] GAJEWSKA, T. (2016). Wybrane metody i wskaźniki pomiaru jakości usług logistycznych. In. Autobusy : technika, eksploatacja, systemy transportowe, 17(6), 1320-1326.

[21] ZYSKA, A., GROFELNIK, I., (2019). Patient safety in the aspect of process and procedures connected with medical services, In. System Safety: Human - Technical Facility - Environment, 1(1), 271-276.

[22] JAGUSIAK-KOCIK, M. (2020). Customer attributes impact on perceived quality of children's furniture - Kano model. In. Conference Quality Production Improvement - CQPI, 2(2), 53-59.

[23] SHOSTACK, G.L. (1982). How to design a service. In. European Journal of Marketing. 16(1), 49-64.

[24] CAI, S., JUN, M. (2003). Internet users' perceptions of online service quality: a comparison of online buyers and information searchers, In. Managing Service Quality, 13(6), 504-519.

[25] MBISE, E.R., TUNINGA, R.S.J. (2016). Measuring business schools' service quality in an emerging market using an extended Servqual instrument. In. South African Journal Of Business Management, 47(1), 61-74.
[26] ULEWICZ, R. (2014). Application of Servqual Method for Evaluation of Quality of Educational Services at the University of Higher Education. In Polish Journal of Management Studies, 9, 254-264.

[27] CIAvOlinO, E., CALCAGNI, A. (2015). Generalized cross entropy method for analysing the SERVQUAL model. In. Journal of $A$ plied Statistics, 42(3), 520-534.

[28] JAIN, S.K, GUPTA, G. (2004) Measuring Service Quality: Servqual vs. Servperf Scales.In. Vikalpa: The Journal for Decision Makers, 29(2), 25-38.

[29] MAHMOUD, A.B., KHALIFA, B. (2015). A confirmatory factor analysis for Servperf instrument based on a sample of students from Syrian universities. In. Education And Training, 57(3), 343-359.

[30] KUCIŃSKA, A., KOŁOSOWSKI, M., (2009), Zastosowanie metody SERPERV do oceny zadowolenia klienta. Konferencja In. Innowacje w Zarzadzaniu i Insiynierii Produkccji, Zakopane.

[31] GILMORE, A. (2003). Services Marketing and Management, Sage, Londyn.

[32] BRADY, M.K., CRONIN, J.J., BRAND, R.R. (2002). Performance-only measurement of service quality: a replication and extension. In. Journal of Business Research, 55(1), 17-31.

[33] BOULDING, W., KALRA, A., STAELIN, R., ZEITHAML, V.A. (1993). A Dynamic Process Model of Service Quality: From Expectations to Behavioral Intentions. In. Journal of Marketing Research, 30(1), 7-27.

[34] BABAKUS, E., BOLLER, G.W. (1992). An Empirical Assessment of the Servqual Scale. In. Journal of Business Research, 24(3), 253-68.

[35] CZAJKOWSKA, A., INGALDI, M. (2019). Identification of the Needs and Expectations of University Students from Engineering Courses on the Example of a University in Poland, In. System Safety: Human - Technical Facility - Environment, 1(1), 498-505.

[36] HAIR, J.F. JR., BABIN, B., MONEY, A.H., \& SAMOUEL, P. (2003). Essential of business research methods. John Wiley \& Sons, United States of America.

[37] HSU, S.H. (2008). Developing an index for online customer satisfaction: Adaptation of American Customer Satisfaction Index. In. Expert Systems with Applications, 34(4), 3033-3042. 
[38] KLIMECKA-TATAR, D., PAWŁOWSKA, G., RADOMSKA, K. (2020). Preliminary Quality Control of Magnetic Materials for applications in Restorative Medicine - Quantitative Analysis of Structural Homogeneity of RE-MB / Polymer Composites. Manufacturing Technology, 20(1), 49-54.

[39] KAPUSTKA, K., ZIEGMANN, G., KLIMECKA-TATAR, D., SARA NAKONCZY, S. (2020). Process management and technological challenges in the aspect of pernament magnets recycling - the second life of neodymium magnets. Manufacturing Technology, 20(5), 617-624.

[40] KNOP, K. (2020). Indicating and analysis the interrelation between terms - visual: management, control, inspection and testing. Production Engineering Arcbives, 26(3), 110-121.

[41] DABYLOVA, M., SROKA, M., ALIBEKOVA, G. (2020). New challenges in education processes at technical faculties in Asian countries of the former Soviet Union. Production Engineering Archives, 26(1), 15-18. 